\title{
Historical Cartography Analysis for a Design of Cultural Itineraries in the Lower Guadalquivir
}

\author{
Rebeca Merino del Río a, b, * \\ a Department of Architectural Design, University of Seville, rmdelrio@us.es \\ ${ }^{b}$ Department of Architecture, University of Florence, rebeca.merinodelrio@unifi.it \\ * Corresponding author
}

Keywords: Historical cartography, analysis, design, cultural itineraries, lower Guadalquivir

\begin{abstract}
:
Historical cartography constitutes one of the primary sources that allows us to substantiate the protection, management and planning actions with regards to the landscape. Reviewing it facilitates, for example, the uncovering and verification of the ancient patterns of settlements and land connections. This article explores the way in which the systematic review of the historical maps supports the analysis of the territorialisation processes. This analysis allows us to detect and identify those territorial assets with heritage values that have characterised the cultural landscape at different times. A graphic device is proposed to facilitate the synthesis and subsequent interpretation of the rules for transforming the territorial heritage that have influenced the evolution of the cultural landscape. This interpretation is essential to guarantee the effectiveness of certain design strategies that operate in terms of the landscape, such as cultural itineraries. This process of analysis and synthesis is exemplified through the case study of Itálica's buffer zone, in the area of the lower Guadalquivir (Merino, Linares \& Tejedor, 2021).
\end{abstract}

In order to move towards a design for the cultural itineraries capable of interpreting the dynamics of cultural landscape formation, an analytical method is proposed which is based on a series of criteria underlying the territorialist approach to the integrated project for the territory (Poli, 2018, pp. 13-32). In this approach, the landscape aspect is incorporated into planning instruments through the territorial heritage, which comprises the identity values of the cultural landscape in a wider sense. The territorial heritage acquires, thus, an extensive meaning that refers to the natural, cultural and landscape heritage. The method is focused on the detection and identification of those material sediments, which are part of the territorial assets, that possess landscape heritage and identity values. The aim is to guarantee that the design of the itineraries has an effect on those elements that have characterised and influenced the evolution of the cultural landscape. Thus, integration of the landscape aspect by means of the territorial heritage allows us to face one of the major challenges of territorial planning and management (Troitiño, 2011).

The detection and identification of the material sediments with heritage value is possible by analysing the territorialisation processes. This analysis puts the focus on the historical and structural dimension of the territorial heritage (Magnaghi, 2017). From a diachronic perspective, the intervals that delimit the phases of territorialisation are established. From a synchronic point of view, the elements of the anthropic structure that are characteristic of the cultural landscape for each phase of territorialisation are identified (Merino, 2020). Both perspectives are complementary and should be considered simultaneously because of their intricate nature. The comparative analysis of historical cartography and manuscripts, scientific literature, and georeferenced datasets should take both dimensions into account. The subsequent synthesis and interpretation of the information enable us to recognise those elements of the territorial heritage with identity values that have influenced the evolution of the cultural landscape and that should therefore be considered in a potential restitution of its dynamics of formation.

To illustrate this process, Itálica's buffer zone is considered as a case study. The archaeological site of Itálica is located in the area of the lower Guadalquivir. Currently, its candidature to be included in UNESCO's World Heritage List is being reviewed. The site constitutes a clear example of a decontextualised immovable asset located within a profoundly altered landscape, which has, however, a high heritage value. The analysis of the territorialisation processes supported by a review of the historical cartography, together with the synthesised interpretations, are the basis for an itinerary project aimed at restoring the cultural landscape formation dynamics in Itálica's buffer zone. Due to the required circumspection of this essay, the interpretation of the information from the analysis of the territorialisation processes is limited here to the production of the maps of the phases and the synthesis map of the territorial heritage.

The specific method followed to produce the synthesis maps begins with archival research and cataloguing the sample. An analysis aimed at describing the territory formation process is conducted afterwards. In this regard, the scientific production of Chías and Abad is a significant point of reference on a national level. Their hypotheses regarding the formation of different national territories are grounded on the analysis of the bibliographical sources and of the historical maps and plans. The analysis is applied to different case studies (Chías, 2018), such as the territory of Castilla 
y León, the bay of Cádiz, the areas surrounding the bridge of Alcántara or the Monastery of El Escorial. Thus, its adaptability to different fields (architectural, urban and territorial) has been demonstrated. This kind of analysis, which belongs to the documentary research field, constitutes, in our case, part of a wider method to design cultural itineraries. Furthermore, our analysis focuses on one hand on the detection and identification of the main elements of the territorial heritage that have influenced the evolution of the territory, and on the other on the establishment of the phases of territorialisation.

Returning to our case study, the sample subject to analysis, which has been obtained from different catalogues, national and international, is limited to those graphic records in which Itálica or its neighbouring settlements are represented on different levels (national, regional and local). The information from the analysis of the historical cartography and manuscripts is compared to the scientific literature and the georeferenced datasets in order to make assumptions on the sequence of phases of territorialisation and on the spatial organisation of the settlements and terrestrial connections that might have characterised the cultural landscape in each of them.

A series of synthetic maps gathers the conclusions from this comparative analysis. These maps are produced using QGIS software. They are created on an updated cartographic basis formed by datasets from the Andalusian Institute of Statistics and Cartography, specifically, from the repositories Datos Espaciales de Referencia de Andalucia (DERA) and Localizador de Información Espacial de Andalucia (LINE@), and from the Andalusian Historical Heritage Institute (IAPH). For each phase of territorialisation, the spatial organisation of the main urban cores and settlements is highlighted. Special attention is paid to their relative importance when the cartographic and bibliographic records allow for such conclusions. Moreover, the intention is to identify the material evidence of the stretches of road that might have constituted the ancient terrestrial connections that structured the territory. To the extent that this material evidence has characterised the cultural landscape at each phase, they are also part of the territorial heritage. As these synthetic maps do not pursue the historical reconstruction, but the identification in the territory of traces of the ancient organisation of the settlements and the terrestrial connections, no hypotheses regarding the layout of the river courses are included. However, recent contributions in this regard (Borja et al., 2020) have been taken into consideration. The required study to undertake that reconstruction exceeds the scope and objectives of this research, yet it will be subject to consideration for future scientific projects. Nevertheless, the area around the River Guadalquivir and other river courses, to which the variations of the riverbeds have been confined, is identified in an attempt to deal with this matter. This identification relies on edaphology.

\section{Acknowledgements}

This research is framed within the Spanish Ministry of Economy and Competitivity funded project HAR2016-79757-R "Smart Architectural and Archaeological Heritage", coordinated by Prof. Antonio Tejedor, and the Regional Government of Andalusia funded project US-1263780 "Gestión Inteligente y Sostenible del Patrimonio Arquitectónico", coordinated by Prof. Carlos Plaza and Prof. Antonio Tejedor, both ascribed to the University of Seville.

\section{References}

Borja, F., Olmedo, F., Roldán M.E, Borja, C., \& Noguero, M.D. (2020). Rivera de La Algaba versus Rivera de Huelva. In Tejedor, A., Linares, M., López, M., \& Merino, R. (Coords.), Innovación para la gestión integrada del Patrimonio, el Paisaje y el Turismo (pp. 274-303). Editorial Universidad de Sevilla, Ediciones Universidad de Valladolid.

Chías, P. (2018). La representación de la ciudad, del territorio y del paisaje en la Revista EGA: mapas, planos y dibujos. EGA Expresión Gráfica Arquitectónica, 23(34), 106-121. https://doi.org/10.4995/ega.2018.10850.

Magnaghi, A. (2017). La storia del territorio nell'approccio territorialista all'urbanistica e alla pianificazione. Scienze del Territorio, O(5), 32-41. https://doi.org/10.13128/Scienze_Territorio-22229.

Merino, R. (2020). Criteria for Designing Cultural Itineraries as a Strategy for Restoring the Dynamics of Cultural Landscape Formation. Some Research Notes about the Case Study of Itálica. Ri-Vista. Research for Landscape Architecture, 18(1), 238-263. https://doi.org/10.13128/rv-8093.

Merino del Río, R., Linares Gómez del Pulgar, M., \& Tejedor Cabrera, A. (2021). Análisis de los procesos de territorialización en el bajo Guadalquivir a través de la cartografía histórica. EGA Expresión Gráfica Arquitectónica, 26(41), 102-119. https://doi.org/10.4995/ega.2021.14255.

Poli, D., Donadieu, P. (Prol.), \& Magnaghi, A. (Epil.). (2018). Formes et figures du projet local: la patrimonialisation contemporaine du territoire. Rosenberg e Sellier.

Troitiño, M.A. (2011). Territorio, patrimonio y paisaje: desafíos de una ordenación y gestión inteligentes. Ciudad y Territorio-Estudios Territoriales, XLIII(169-170), 561-569. 